\title{
An assessment of habitat conditions for fish species in the Guem River, Korea
}

\author{
J. Kim, D. K. Koh \& S. Cho \\ Water Resources Research Center, K-water Institute, \\ Korea Water Resources Corporation, Korea
}

\begin{abstract}
The purpose of this study is to assess habitat conditions for fish species in the Geum River, Korea through monitoring ecological environment and building database for fish species. For this purpose, 11 stations were monitored from October 2007 to September 2009. A total of 45 fish species were sampled at the monitored stations. As a result, the study found three sensitive species (including Zacco platypus (28.2\%), Z. koreanus (13.1\%) and Coreoleuciscus splendidus $(10.5 \%))$ to be dominant in the fish community in the Geum River. Based on a dendrogram with $50 \%$ in similarity rate, sampling stations were subdivided into 5 groups. As a result, it was revealed that the Index of Biological Integrity (IBI) and Qualitative Habitat Evaluation Index (QHEI) decreased from upstream to downstream along the river. The Habitat Suitability Index (HSI) for C. splendidus was determined according to three different stages in terms of life cycle: adult-spawning stage (April to June), adult-juvenile stage (July to September) and adult-immature stage (October to March). The optimal ecological flowrate was estimated at $6.5 \mathrm{~m}^{3} / \mathrm{s}$ for the adult-spawning and adultimmature stage, and $8.5 \mathrm{~m}^{3} / \mathrm{s}$ for the adult-juvenile stage. On the whole, the river seems to be relatively well protected from anthropogenic activities.
\end{abstract}

Keywords: aquatic habitat(s), fish, IBI, QHEI, HSI, PHABSIM, Guem River.

\section{Introduction}

Freshwater fishes are the highest vertebrates in terms of species diversity. At the same time, the most endangered (Duncan and Lockwood [3]) 50 of 212 fish species $(23.6 \%)$ found throughout the Korean peninsula known to be endemic to Korea in the mountainous regions (Kim and Park [20]). Although it is true that protection areas (e.g. national parks) play an important role in conserving Korean 
freshwater fish, there is still a need to better identify their values in terms of biogeographical fish diversity and factors that have impacts on fish communities. Most of mountainous streams in Korea are shallow and intermittent with little stream flow during the dry season (October to June). Cultivation and irrigation activities have hydrologically modified many of headwater streams (Joo et al. [13]) and other anthropogenic activities (e.g. land clearing, construction of small dams and roads, fires, mining, etc.) have caused physiochemical alterations in mountain streams. In Korea, among others, weirs function as very important structures that create pools and habitats for fish during the dry season (Joo et al. [13]). But poorly-designed weirs often interrupt continuous stream flow. This, in turn, impedes their dispersal and migration.

Karr [14] introduced a concept of IBI using fish assemblages to assess water environment based on physical, chemical, and biological conditions for small streams in the mid-western USA. Since then, 35 states have adopted this index (Karr et al. [16]), followed by many other countries, including France (Oberdorff and Hughes [24], Oberdorff and Porcher [25]), Guinea (Hugueny et al. [10]), Namibia (Hocutte et al. [8]), India (Ganasan and Hughes [4]), Japan (Koizumi and Matsumiya. [21]), and Australia (Harris [7]).

The IBI approach is a quantitative multi-metric method used worldwide since it is cost-effective (Ohio EPA [26], Karr and Dionne [16], Barbour et al. [2], Karr and $\mathrm{Chu}[15])$. The method enables the structural and functional assessment of various aspects of fish communities in a specific region or habitat.

Prior to the application of the IBI method, the regional modification of metric numbers and characteristics are required. This is because there are differences, for example, in the ecological distribution of fish species, climate, and habitat. This study attempted to apply the IBI metrics to the Geum River and identify conditions required for its soundness by assessing fishes, flow regime, and habitat requirements.

\section{Materials and methods}

\subsection{Study area}

The Geum River is located at the west of Korea (Figure 1) which is the third largest river system in Korea. Its catchment area is $9,835.3 \mathrm{~km}^{2}$ and corresponds to almost one tenth of the country. Its length is about $130 \mathrm{~km}$ in the direction of the east to the west and about $160 \mathrm{~km}$ from the north to the south. Its basin borders on the Han River basin in the north; the Mangyeong River and the Seomjin River basins in the south; the Yellow sea in the west; and the Nakdong River basin in the east. There are two multipurpose dams in the Geum River: the Daecheong Dam (constructed in December 1980) and the Yongdam Dam (constructed in October 2001).

\subsection{Sampling fish and IBI analysis}

Fish sampling has conducted at 11 stations in the Geum River from October 2007 to September 2009 (see Figure 1). Table 1 shows the summary of their 
environmental characteristics. Fish samples were captured using a cast net (mesh size: $5 \times 5 \mathrm{~mm})$ and a kick net $(3 \times 3 \mathrm{~mm})$ to improve efficiency and applicability in sampling sentinel species at the stations. To assess quantitative fish community, sampling was implemented at pool, riffle, and run with 150 to $200 \mathrm{~m}$ intervals from downstream to upstream and 60 to $70 \mathrm{~min}$ sampling per station.

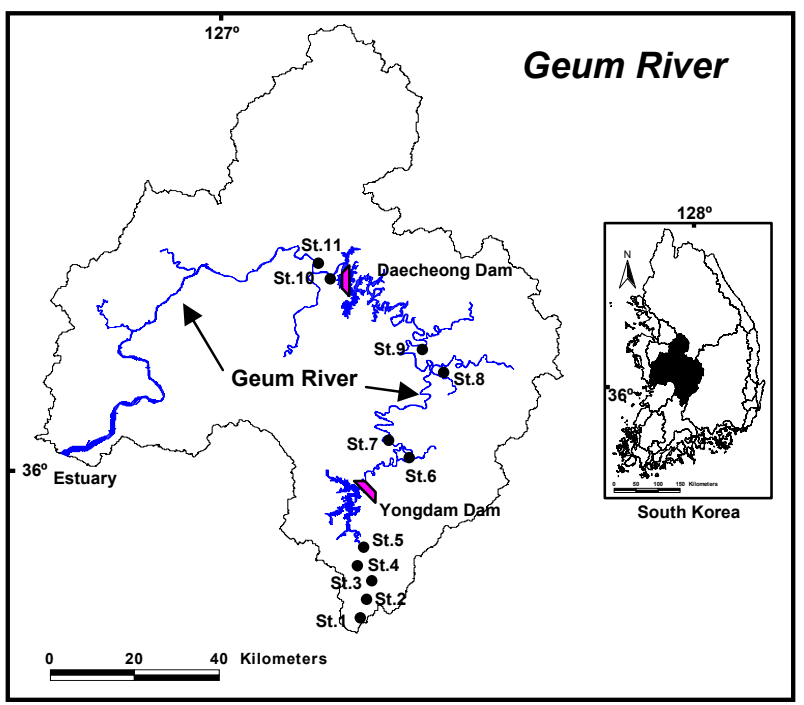

Figure 1: $\quad$ Sampling stations for fish fauna survey in the Geum River.

Table 1: Environmental characteristics at the 11 stations in the Geum River.

\begin{tabular}{ccccccc}
\hline St. & Stream Order Width $(\mathrm{m})$ & Velocity $(\mathrm{m} / \mathrm{s})$ & Depth $(\mathrm{m})$ & Type of River & Size $^{\mathrm{O}}$ of Substrates \\
\hline 1 & 1 & $2-5$ & $0.1-0.5$ & $0.1-0.3$ & B3-B4 & $3.0-5.0$ \\
2 & 2 & $5-10$ & $0.1-0.5$ & $0.2-0.3$ & B3-B4 & $3.0-5.0$ \\
3 & 3 & $15-20$ & $0.2-0.8$ & $0.2-1.0$ & B2-B3 & $2.0-4.0$ \\
4 & 4 & $20-30$ & $0.1-0.7$ & $0.2-1.0$ & B3-B4 & $3.0-5.0$ \\
5 & 5 & $20-30$ & $0.3-0.5$ & $0.3-1.2$ & B3-B4 & $3.0-5.0$ \\
6 & 5 & $40-50$ & $0.2-1.0$ & $0.3-1.2$ & B3-B4 & $3.0-5.0$ \\
7 & 5 & $60-100$ & $0.1-1.2$ & $0.3-1.3$ & B3-B4 & $3.0-5.0$ \\
8 & 6 & $40-60$ & $0.1-1.0$ & $0.3-1.1$ & B3-B4 & $3.0-5.0$ \\
9 & 6 & $150-200$ & $0.3-1.4$ & $0.2-1.5$ & B4-B5 & $2.0-4.0$ \\
10 & 6 & $200-250$ & $0.2-1.3$ & $0.3-1.5$ & B3-B4 & $3.0-5.0$ \\
11 & 6 & $250-300$ & $0.2-1.2$ & $0.4-1.5$ & B4-B5 & $2.0-4.0$ \\
\hline
\end{tabular}

${ }^{\mathrm{a}} \mathrm{B} 3$ : meandering river - cobble, B4: meandering river - gravel, B5: meandering river sand.

${ }^{\mathrm{b}} 1.0$ (silts): $<0.062 \mathrm{~mm}, 2.0$ (sand): $0.062-2.0 \mathrm{~mm}, 3.0$ (fine gravels): $2.0-16.0 \mathrm{~mm}$, 4.0 (coarse gravels): 16.0-64.0 mm, 5.0 (cobbles): $64.0-256.0 \mathrm{~mm}, 6.0$ (boulders): $>256.0 \mathrm{~mm}$. 
Captured fish samples were fixed using a buffered formalin solution $(10 \%)$ for their counting, and then stored in a 5\% formalin solution. They were identified using methods proposed by (Kim and Park [20]), based on (Nelson's classification system [23]). Their scientific names and authorities were also determined using methods proposed by (Kim and Park [20]).

For cluster analysis, similarity values were estimated using density data on various species of fishes, based on a method used by (Ludwig and Reynolds [22]).

The body weight and total length of Coreoleusiscus splendidus captured at St. 6 to 9 were measured using an electronic balance (JW-1, Korea) and a digital Vernier calipers (CD-20CP, Japan), respectively. To obtain information about gonad conditions, GSI (Gonad Somatic Index) was calculated as a percentage of total body weight.

\subsection{Data analysis using IBI}

Fish community analysis was based on the 10-metric IBI model. There is also the 12-metric model (Karr et al. [17]). Because of difficulties in assessing metrics for long-lived fishes and primary carnivores, this model could not be used. The attributes of the following four metrics among 10 original metrics proposed by (Karr et al. [17]) were modified and replaced for regional applications such as native species richness, benthic-species richness, watercolumn species richness, and percentage of non-native individuals (US EPA, [35]). The classification of tolerance designation, trophic status, and origin of fish species sampled were based on a previous study (Kim [19]). Each metric was given applicable scores (1, 3 or 5$)$. " 1 " and " 5 " mean the worst and the best respectively.

Scoring criteria for each metric were based on maximum species-richness line as developed by (Rankin and Yoder [31]). These scores (5, 3, and 1) were summed up to derive an IBI value at each station. Integrity class as developed by (Karr [14]) was modified and assessed at each station. The highest value was 50 which indicates the status of non-disturbance in fish communities. The lowest value was 10 which indicates fish communities in a very poor status. Thus, each station was grouped into five integrity classes: Excellent (47 to 50), Good (38 to 42), Fair (30 to 34), Poor (18 to 24 ), and Very Poor (3 to 12). The 10-metrics IBI model was configured to consist of three groups: species richness and composition, trophic composition, and fish abundance and soundness condition.

\subsection{QHEI (Qualitative Habitat Evaluation Index) analysis}

To assess QHEI, stream habitat data were also collected using nationwide database and ten generally accepted habitat parameters (US EPA [33, 34]). QHEI is a qualitative measurement of primary characteristics of stream habitats that may influence the soundness of fish communities (Rankin [29, 30]). These parameters were subdivided into four categories, based on (US EPA [33, 34]) such as Optimal, Sub-optimal, Marginal, and Poor. Habitat soundness was assessed by total scores obtained from those seven parameters, and categorized 
into four levels such as Excellent (>162), Good (148-104), Fair (90-46), and Poor $(<32)$.

\subsection{Assessment of HSI (Habitat Suitability Index)}

The HSI model enables the assessment of physical habitat suitability in each cell within a study area, based on the observed organism population and environmental factors. This model uses aggregated HSI values which range from zero ("not suitable") to one ("most suitable") for a specific organism. In-situ measured data were used to obtain HSI values in the survey area. Frequency distributions were estimated through dividing each frequency value by a maximum frequency value, and used to normalize HSI values. Conditions with the highest frequency are considered as the most suitable for fish habitats. Based on measured data (velocity, depth, and size of substrates), OEF (Optimal Ecological Flowrate) was estimated through HSI for C. splendidus (selected as icon species for optimal ecological flow estimation).

\subsection{Estimation of optimal ecological flow}

PHABSIM, a physical habitat simulation system, was used to estimate optimal flowrate for fish habitats at each representative river reach. Optimal flow regime for fish habitats was determined by estimating optimal flowrate using a relation curve between WUA (Weighted Usable Area) and discharge (obtained through the combined use of a hydraulic model and HSI).

Optimal flow regime suitable for fish habitats can be determined through hydraulic modeling. In this modeling, WUA is estimated by multiplying the area of a cell by a combined HSI for the cell as follows:

$$
W U A=\sum_{i=1}^{n} A_{i} \times C_{i}
$$

where $A_{i}$ and $C_{i}$ refer to the area of cell $i$ and a combined HSI for cell $i$, respectively.

Gordon et al. [5] estimated and determined combined HSI and $\mathrm{Ci}$, based on suitability criteria for depth, velocity, and size of substrates, using standard computation method, geometric mean method, and minimum value method. In this study, the standard computation method was employed as follows (Palmer and Snyder [27]):

$$
C_{i}=f\left(v_{i}\right) \times f\left(d_{i}\right) \times f\left(c_{i}\right)
$$

where $v_{i}$ and $d_{i}$ refer to HSI of cell $i$ at a specific velocity $(v)$ and at a specific flow depth $(d)$, respectively. $\mathrm{c}_{i}$ means to HSI of cell $i$ at a specific size of substrates (c). 


\section{Results and discussion}

\subsection{Fish assemblages and cluster similarity analysis}

Over 3,400 fish captured in the target river (i.e. the Gemu River) were classified into 45 species. Cyprinidae, a dominant family in the river basin, accounted for $66.7 \%$ (30 species in total) of the sampled fish species. One of the main characteristics of fish fauna is related to the fact that Cyprinidae occupied more than $50 \%$ of captured fishes in the rivers (Jeon [12]). It was revealed that Zacco platypus was the most abundant fish species (28.2\%) in relative abundance (RA), and Z. koreanus (13.1\%), C. splendidus (10.5\%), and Tridentiger brevispinis $(5.9 \%)$ were subdominant species. Overall, 20 species were found to be endemic to Korea (five families with $44.4 \%$ in RA, slightly lower than $50.9 \%$ reported by An et al. [1]). Four individual Cyprinus cuvieri, one of foreign species, were sampled at St. 11. Three endangered species (including Pseudopungtungia nigra, Gobiobotia macrocephala, and G. brevibarba) were sampled. They accounted for about $9.0 \%$ of total fish samples.

The appearance rate of $Z$. platypus and $Z$. koreanus varied depending on stream order. Z. koreanus (58.4\%) was found as a dominant species in the $3^{\text {rd }}$ or lower stream order (St. 3). The appearance rate of the Z. koreanus and Z. platypus were $33.3 \%$ and $43.3 \%$, respectively in the $4^{\text {th }}$ stream order (St. 4$)$. In the $5^{\text {th }}$ or lower stream order (St. 5), Z. platypus were more dominant than Z. koreanus. Otherwise, Hur and Kim [11] reported Z. koreanus were more dominant than Z. platypus, especially in the $3^{\text {rd }}$ or lower stream order. Kim et al. [18] held that the similar appearance rate of $Z$. koreanus and Z. platypus in the $5^{\text {th }}$ order streams would contribute to the development of rivalry relations in acquiring ecological niche.

Based on a dendrogram with $50 \%$ in similarity rate, sampling stations were subdivided into 5 groups. Group A was distributed in the most upstream area (St. 1 to 2) with narrow channels and simply-structured habitats. Group B was distributed over midstream to upstream (St. 3 to 5). Group C was distributed in the midstream (St. 6 to 9). It was found that artificial hydraulic structures (especially, for example, the Yongdam Dam) were one of the main factors that changed fish community. This, in turn, contributed to a division between Group B and C. Gorman and Karr [6] reported that there are close relations between fish habitats and structure of fish communities. Hong et al. [9] held that hydraulic structures tended to contribute to the simplification of fish communities at upstream and downstream. This finding indicates that a division between Groups B-C and Groups C-D-E (located between the Yongdam Dam and the Daecheong Dam) were related mainly to the dam construction. This, in turn, resulted in differences in the structures of fish communities.

\subsection{IBI and QHEI values}

As shown in Figure 2, an average of IBI values estimated at St. 1 to 5, upstream of the Yongdam Dam showed a tendency to decrease toward downstream. The 
estimated IBI scores ranged from 24.7 to 38.0 with $30.7 \pm 4.5$ on the average, rendering each station as ecologically Fair to Poor. Based on criteria proposed by (Karr [14]), however, there was no station which was rendered as "Excellent." This was, for example, because the appearance rate of species endemic to Korea (such as Rhynchocypris oxycephalus, Liobagrus mediadiposalis, Odontobutis platycephala and Coreoperca herzi) was relatively low, when compared with that of a previous study (carried out by An et al. [1]).

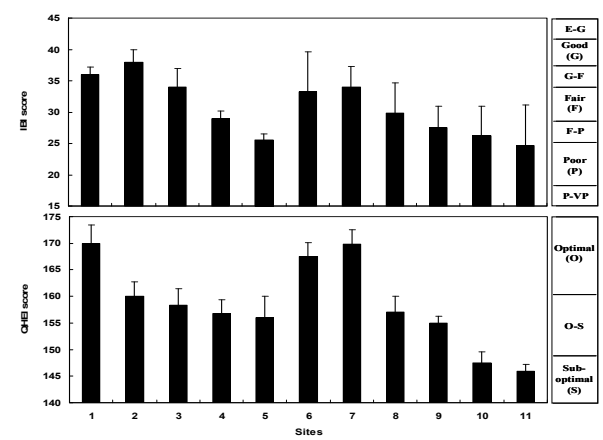

Figure 2: $\quad$ IBI and QHEI.

In this study, IBI and QHEI values showed a similar tendency to decrease toward downstream, except for two stations (including St. 10 and 11) located downstream. The estimation of QHEI values showed that each station was in a Fair-to-Good status.

Figure 3 shows a linear relation between the IBI and QHEI values. Similarly to the results of this study, Yeom et al. [36] reported that an increase in IBI values would lead to an increase in QHEI values. Plafkin et al. [28] supported an assumption that the quality of fish habitats would be positively correlated with IBI values, and the deterioration of habitat quality could reduce fish richness, and consequently affect trophic structures.

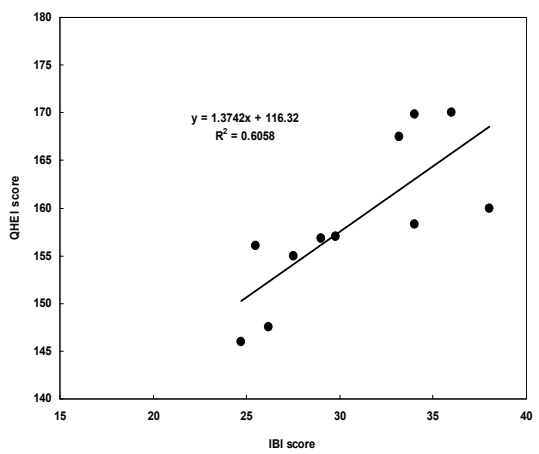

Figure 3: $\quad$ Relations between IBI and QHEI. 


\subsection{Habitat model}

Figure 4 shows the estimation of GSI values for $C$. splendidus, based on the analysis of 30 male and female fish species captured at St. 6 to 9 from June 2008 to July 2009. Their spawning stage extends from April to June. To compute OEF using PHASIM, HSI for C. splendidus was estimated at St. 6. Their life cycle was subdivided into three stages: spawning stage (April to June), juvenile stage (July to September), and immature stage (October to March).

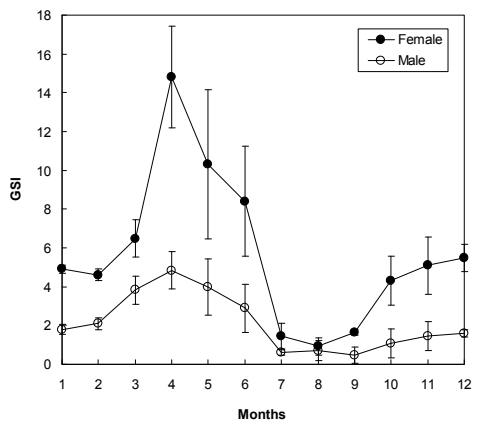

Figure 4: Monthly variations in GSI for female and male Coreoleuciscus splendidus captured at St. 6 to 9. (June 2008 to May 2009).

Salmonidae go through a spawning stage once in their lifetime. This is the reason why their life cycle can be distinctly subdivided (for example, spawning stage, juvenile stage, and immature stage). However, most of fishes in Korea go through multiple spawning stages in their lifetime; they coexist and grow with their hatched juvenile. Kim and Park [20] reported that a spawning stage for C. splendidus extended from April to May. However, due to a regional difference in climate, there may be differences in the ending time of a spawning stage. There may be also cases where fishes postpone or refuse spawning, when environmental conditions for habitats deteriorate. Other factors that have impacts on such conditions include variations in flowrates and water temperature. Some fish species go through multiple spawning stages for months or one to two spawning stage in a year. To assess OEF required for fish habitats, the identification of life cycle for each fish species is very important.

OEF required for $C$. splendidus was estimated using PHABSIM. They were selected as icon species, based on HSI values estimated for velocity, depth, and size of substrates (Table 2).

Figure 5 shows relations between WUA and flowrate for $C$. splendidus computed using PHABSIM. Optimal flowrate varies depending on different HSI values during the life cycle. OEF for $C$. splendidus was estimated at $6.5 \mathrm{~cm}$ for the adult-spawning stage and adult-immature stage, and $8.5 \mathrm{~cm}$ for the adultjuvenile stage. It is judged that an increase in OEF, especially in the adultjuvenile stage, resulted from an increase in flowrate in the river basin during the rainy season. 
Table 2: Seasonal variations in HSI values for velocity, depth, and size of substrates at St. 6.

\begin{tabular}{ccccc}
\hline Name of species & Life stage (Month) & Velocity (m/s) & Depth (m) & Size of substrates ${ }^{\mathrm{a}}$ \\
\hline \multirow{3}{*}{$\begin{array}{c}\text { Coreoleuciscus } \\
\text { splendidus }\end{array}$} & Adult-spawning (4-6) & $0.1-0.4$ & $0.3-0.5$ & $3.0-4.0$ \\
\cline { 2 - 5 } & Adult-juvenile (7-9) & $0.2-0.6$ & $0.2-0.6$ & $3.0-4.0$ \\
\cline { 2 - 5 } & Adult-immature (10-3) & $0.2-0.5$ & $0.2-0.5$ & $3.0-4.0$ \\
\hline
\end{tabular}

${ }^{\mathrm{a}} 1.0$ (silts): $<0.062 \mathrm{~mm}, 2.0$ (sand): $0.062-2.0 \mathrm{~mm}, 3.0$ (fine gravels): $2.0-16.0 \mathrm{~mm}$, 4.0 (coarse gravels): $16.0-64.0 \mathrm{~mm}, 5.0$ (cobbles): $64.0-256.0 \mathrm{~mm}, 6.0$ (boulders): $>256.0 \mathrm{~mm}$.

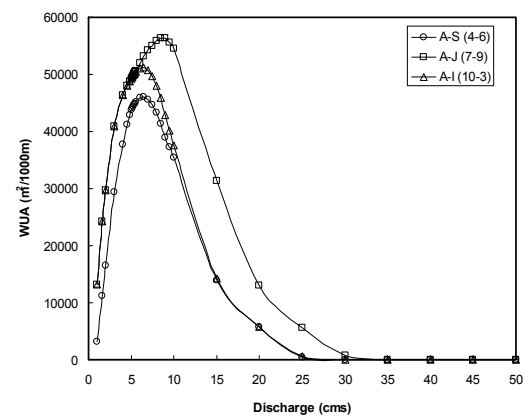

Figure 5: Variations in WUA to discharge at St. 6. (A-S: adult-spawning, A-J: adult-juvenile, A-I: adult-immature)

Figure 6 shows the WUA of each cell for $C$. splendidus. WUA for the adultjuvenile stage $\left(56,353.7 \mathrm{~m}^{2} / 1000 \mathrm{~m}\right)$ increased more than WUA for the adultspawning stage $\left(45,989.9 \mathrm{~m}^{2} / 1000 \mathrm{~m}\right)$. An increase in flowrate did not change each cross sectional WUA in the center. However, WUA estimated at the left and right bank increased. The spawning and hatching stage for $C$. splendidus includes April to June and their juvenile stage includes July to September. An increase in flowrate from July to September is a good living condition for juveniles. Annual and perennial weeds inhabiting at open and closed pools on the
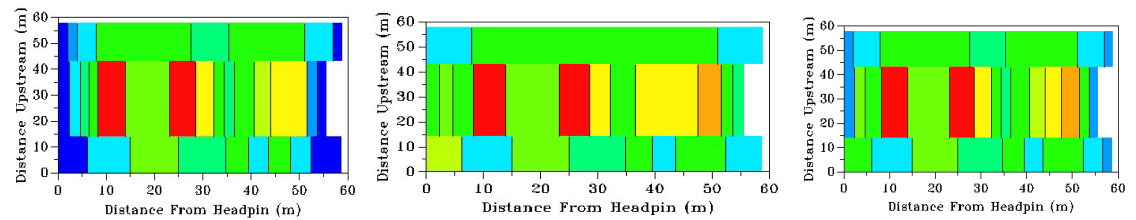

(a) Adult-Spawning (6.5 cm) (b) Adult-Juveniles (8.5 $\mathrm{cm})$, Adult-Immature $(6.5 \mathrm{~cm})$
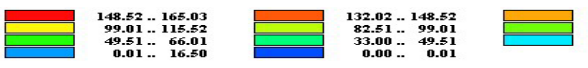

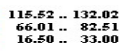

Figure 6: Variations in WUA to flowrate at St. 6. (Coreoleuciscus splendidus). 
left and right bank provides hatched juvenile with shelters from predatory animals. In this study, $C$. splendidus with about $3 \mathrm{~cm}$ in length were sampled near the left and right channel bank or in pools in September.

\section{Conclusion}

The purpose of this study is to assess habitat conditions for fish species in the Geum River through monitoring ecological environment and building related database.

Of species of fishes sampled totaling up to 45 in number, three sensitive species (including Zacco platypus (28.2\%), Z. koreanus (13.1\%), and Coreoleuciscus splendidus $(10.5 \%)$ ) were found to be dominant species in fish community in the river. Sampling stations were subdivided into 5 groups, based on a dendrogram with $50 \%$ in similarity rate. It was revealed that IBI and QHEI decreased from upstream to downstream along the river. HSI's for $C$. splendidus were determined according to three different stages in terms of their life cycle: adult-spawning stage (April to June), adult-juvenile stage (July to September), and adult-immature stage (October to March). OEF (optimal ecological flowrate) was estimated at $6.5 \mathrm{~m}^{3} / \mathrm{s}$ for the adult-spawning and adult-immature stage, and $8.5 \mathrm{~m}^{3} / \mathrm{s}$ for the adult-juvenile stage.

It was revealed that species of fishes including endemic species and protection species frequently appeared in the Geum River, when compared with other rivers in Korea; still, consistent measures for its environmental protection and maintenance are ecologically required. On the whole, the Geum River has been relatively well protected from anthropogenic activities that may have adverse impacts on endangered species (including species endemic to Korea).

\section{Acknowledgements}

This study was backed up by the Technical Innovation of Construction Program (Ecoriver21, 06B01) that is funded by the Ministry of Land, Transport and Maritime Affairs of Korea.

\section{References}

[1] An, K.G., Hong, Y.P., Kim, J.K., Choi, S.S., Studies on zonation and community analysis of freshwater fish in Kum River, Korean J. Limnol. 25, 99-122, 1992.

[2] Barbour, M.T., Gerritsen, J., Snyder, B.D., Stribling, J.B., Rapid bioassessment protocols for Use in streams and wadeable rivers: Periphyton, benthic macroinvertebrates and fish. 2nd ed. Washington, DC: US EPA, Office of Water, EPA 841-B-99-002, 1999.

[3] Duncan, J.R., Lockwood, J.L., Extinction in a field of bullets: a search for the causes in the decline of the world's freshwater fishes. Biological Conservation 102, 97-105, 2001.

[4] Ganasan, V., Hughes, R.M., Application of Index of Biological Integrity (IBI) to fish assemblages of the rivers Khan and Kshipra (Madhya Pradesh). Freshw. Biol. 40, 12-8, 1998. 
[5] Gordon, N.D., McMahon, T.A., Finlatson, B.L., Stream Hydrology: An Introduction for Ecologists. John Wiley \& Sons, New York, NY.

[6] Gorman, O.T., Karr, J.R., 1978. Habitat structure and stream fish communities. Ecology 59, 507-515, 1993.

[7] Harris, J.H., The use of fish in ecological assessments. Aust. J. Ecol. 20, 65-80, 1995

[8] Hocutte, C.H., Johnson, P.N., Hay, C., VanZyl, B.J., Biological basis of water quality assessment: the Kavango River, Namibia. Rev. Hydrobiol. Trop. 27, 361-84, 1994.

[9] Hong, Y.P., Chang, M.H., Kang, H., Choi, S.S., The fish community of the Ungchon stream around the new dam intended area. Korean J. Environ. Biol. 17, 79-88, 1999.

[10] Hugueny, B.S., Camara, B., Samoura, B., Magassouba, M., Applying an index of biotic integrity based on communities in a West African River. Hydrobiologia 331, 71- 8, 1996.

[11] Hur, J.W., Kim, J.K., Assessment of riverine health condition and estimation of optimal ecological flowrate considering fish habitat in downstream of Yongdam dam. J. Korea Water Res. Assoc. 42, 481-491, 2009.

[12] Jeon, S.R., Studies on the distribution of freshwater fishes from Korea. Ph.D. Thesis, Choongang Univ., 91 pp., 1980.

[13] Joo, G.J., Kim, H.W., Ha, K., The development of stream ecology and current status in Korea. Korean J. Ecol. 20, 69-78, 1997.

[14] Karr, J.R., Assessment of biotic integrity using fish communities. Fisheries 6, 21-27, 1981.

[15] Karr, J.R., Chu, E.W., Restoring life in running waters: better biological monitoring. Washington, DC: Inland Press, 1999.

[16] Karr, J.R., Dionne, M., Designing surveys to assess biological integrity in lakes and reservoirs, in biological criteria. Research and regulationproceedings of a symposium. Washington, DC, USA: US EPA Office of Waters. 62-72. EPA-440/5-91-005, 1991.

[17] Karr, J.R., Fausch, K.D., Angermeier, P.L., Yant, P.R., Schlosser, I.J., Assessing biological integrity in running water: a method and its rationale. Illinois national history survey; 1986. Special Publication 5, Champaign, IL, 28 pp, 1986.

[18] Kim, C.H., Lee, W.O., Hong, K.E., Lee, C.H., Kim, J.H., Ichthyofauna and fish community structure in Namdae stream, Yangyang, Korea. Korean J. Ichthyol. 18, 112-118, 2006.

[19] Kim, I.S., Encyclopedia of Korean animals and plants. Animal (Freshwater fish) 37, $629 \mathrm{pp}, 1997$.

[20] Kim, I.S., Park, J.Y., Freshwater Fish of Korea. Kyo-Hak Publishing Co, Seoul, Korea, 2002.

[21] Koizumi, N., Matsumiya, Y., Assessment of stream fish habitat based on index of biotic integrity. Bull. Jpn. Soc. Oceanogr. 61, 144- 56, 1997.

[22] Ludwig, J.A., Reynolds, J.F., Statistical ecology. Wiley Interscience. New York. 620 pp, 1988. 
[23] Nelson, J.S., Fishes of the World, third ed. John Wiley and Sons, New York, USA, 1994.

[24] Oberdorff, T., Hughes, R.M., Modification of an index of biotic integrity based on fish assemblages to characterize rivers of the Seine Basin, France. Hydrobiologia 228, 117-130, 1992.

[25] Oberdorff, T., Porcher, P.J., An index of biotic integrity to assess biological impacts of salmonid farm effluents on receiving waters. Aquaculture 119, 219-35, 1994.

[26] Ohio EPA, Biological criteria for the protection of aquatic life. Users manual for biological field assessment of Ohio surface waters, vol. II. Columbus, OH: Division of Water Quality Monitoring and Assessment, Surface Water Section, 1987.

[27] Palmer, R.N., Snyder, R.M., Effects of instream flow requirements on water supply reliability. Water Resources Research 21, 439-446, 1985.

[28] Plafkin, J.L., Barbour, M.T., Porter, K.D., Gross, S.K., Hughes, R.M., Rapid assessment protocols for use in streams and rivers: benthic macroinvertebrates and fish, EPA/444/4-89-001. Washington, DC, USA: Office of Water Regulations and Standards, US EPA, 1989.

[29] Rankin, E.T., The Qualitative Habitat Evaluation Index (QHEI), Rationale, Methods, and Application. Ohio EPA, Division of Water Quality Planning and Assessment, Ecological Assessment Section, Columbus, OH, 1989.

[30] Rankin, E.T., The use of habitat assessments in water resource management programs. In: Davis, W., Simon, T. (Eds.), Biological Assessment and Criteria: Tools for Water Resource Planning and Decision Making. Lewis Publishers, Boca Raton, FL, pp. 181-208, 1995.

[31] Rankin, E.T., Yoder, C.O., Method for deriving maximum species richness lines and other threshold relationships in biological field data. In: Simon $\mathrm{TP}$, editor. Assessing the sustainability and biological integrity of water resources using fish communities. Washington, DC, USA: CRC Press, pp. 611-624, 1999.

[32] Song, H.B., Kwon, O.K., Ecology of Coreoleuciscus splendidus Mori (Cyprinidae) in Hongchon River. Korean J. Limnol. 26, 235-244, 1993.

[33] US EPA, Methods for measuring the acute toxicity of effluents to aquatic organisms, EPA/600/4-78/012, 1983a.

[34] US EPA, Technical support manual: Waterbody surveys and assessment for conducting use attainability analyses. Washington, DC, USA: Office of Water Regulations and Standards, US EPA, 1983b.

[35] US EPA, Fish field and laboratory methods for evaluating the biological integrity of surface waters. EPA 600-R-92-111. Environmental Monitoring systems Laboratory- Cincinnati office of Modeling, Monitoring systems, and quality assurance. Office of Research Development, US EPA, Cincinnati, OH 45268, 1993.

[36] Yeom, D.H., An, K.G., Hong, Y.P., Lee, S.K., Assessment of an index of biological integrity (IBI) using fish assemblages in Keumho River, Korea. Korean J. Environ. Biol. 18, 215-226, 2000. 